\title{
SUDSKI POSTUPCI KOD POVREDA PRAVA RADNIKA NA ZAŠTITU ZDRAVLJA I SIGURNE UVJETE RADA
}

SAŽETAK: Temeljno socijalno pravo radnika je pravo na radne uvjete koji neće štetiti sigurnosti, zdravlju i dostojanstvu radnika. U radu se analizira načelo zaštite radnika i zaštite prava na radu i u vezi s radom, uz prikaz pravne teorije i sudske prakse te se opisuju sudski postupci kod povrede prava radnika na zaštitu zdravlja i sigurne uvjete rada prema zakonima Republike Hrvatske i relevantnim propisima Europske unije. Posebice se analiziraju statistički podaci o predmetnim radnim sporovima te praksa Općinskoga suda u Splitu. Zaštita i ostvarenje ljudskih prava i sloboda složeno je i osjetljivo pitanje, a pravnu podlogu za učinkovitu zaštitu predstavlja međunarodnopravni, univerzalni i regionalni sustav zaštite ljudskih prava i sloboda. U radu se upozorava na potrebu analiziranja pravnih izvora Europske unije te prakse suda Europske unije pri donošenju sudskih odluka kako bi se postigao viši stupanj pravne sigurnosti i ujednačenosti odluka. Autorice zaključuju da se pravilnim i pravodobnim provođenjem propisanih mjera zaštite na radu sudionika radnoga procesa utječe na smanjenje povreda prava radnika te posljedično sudskih sporova zbog povrede prava radnika na zaštitu zdravlja i sigurne uvjete rada.

Ključne riječi: radno pravo, sigurni uvjeti rada, sudski sporovi, zaštita na radu

\section{UVOD}

Načelo zaštite prava radnika na radu i u vezi s radom jedno je od najvažnijih načela radnoga prava. Problem istraživanja ovoga rada je zaštita prava radnika na radu i u vezi s radom kao i utjecaj provođenja propisanih mjera zaštite na radu na zdravlje radnika te posljedično na sudske postupke zbog povrede prava radnika. Predmet istraživanja je način te obim utjecaja provođenja propisanih mjera zaštite na radu na povredu prava radnika na radu i u vezi s radom te na broj $\mathrm{i}$ ishod sudskih postupaka. Navedeni problem istraživanja ima za objekt istraživanja sudske sporove zbog povrede prava radnika te utjecaj provođenja propisanih mjera zaštite na radu na zaštitu radnika i njegovih prava na radu i u svezi s radom. Za

*Mr. sc. Ivana Erceg Ćurić, (Ivana.ErcegCuric@osst.pravosudje. hr), mr. sc. Daniela Pivčević, (Daniela.Pivcevic@osst.pravosudje.hr), Općinski sud u Splitu, Dračevac bb, 21000 Split. potrebe rada provedena je analiza zakonskih akata, obrađene su normativne obveze poslodavca i prava radnika na radu i u svezi s radom te postupci pred Općinskim sudom u Splitu, jer aktualnim istraživanjima predmetna materija nije na ovakav način obrađena u znanstvenoj i stručnoj literaturi uz statistički prikaz broja i ishoda sudskih sporova.

\section{Načelo zaštite radnika i zaštite prava na radu i u vezi s radom}

Načela zaštite osoba radnika na radu i zaštite prava na radu su pravila koja zahtijevaju ponašanje svih sudionika u radnim odnosima prema tim načelima (Geldart et al., 2010.). U reguliranju, ostvarivanju i zaštiti ovih načela sudjeluju brojni subjekti, ministarstva, inspekcije, sudovi, poslodavci i njihove udruge, sindikati i dr. (Rosa Antonia, 2011.). Povreda normi ima za posljedicu kaznene i prekršajne sankcije, odgovornost za štetu, odgovornost za povredu radnih obveza 
i sl. (Učur, 2008.:576). Radnici imaju temeljno socijalno pravo na uvjete rada koji neće štetiti sigurnosti i zdravlju. Ustav Svjetske zdravstvene organizacije (World Health Organization), koja je neovisna specijalizirana ustanova UN-a sa zadatkom pomaganja u ostvarenju najviše razine zdravlja za sve ljude u svijetu, utvrđuje da je ostvarenje najviše razine zdravlja temeljno ljudsko pravo. U preambuli Opće deklaracije o ljudskim pravima (prihvaćena i proglašena na Općoj skupštini UN-a rezolucijom br. 217 /III 10. prosinca 1948.) utvrđeno je da je priznanje urođenoga dostojanstva te jednakih i neotuđivih prava svih članova obitelji temelj slobode, pravde i mira u svijetu te da je važno zaštititi ljudska prava vladavinom prava. Međunarodni pakt o ekonomskim, socijalnim i kulturnim pravima (prihvaćen na Općoj skupštini UN-a, 16. prosinca 1966. godine (rezolucija br. 2200 A /XXI/) stupio na snagu 3. siječnja 1976.) jamči pravo na dostojnu zaradu i dostojan život radnika i njegove obitelji te na zaštitu zdravlja i sigurnost na radu (čl. 7.). Zaštita i ostvarenje ljudskih prava i sloboda, najviših društvenih vrijednosti, jedno je od najsloženijih i najosjetljivijih pitanja u međunarodnoj zajednici, a suvremeni, međunarodnopravni, univerzalni i regionalni sustav zaštite ljudskih prava i sloboda, valjana je pravna podloga za njihovu učinkovitu zaštitu (Barić Punda, 2005.:27).

Republika Hrvatska (RH) članica je Svjetske zdravstvene organizacije, kao i Međunarodne organizacije rada, specijalizirane agencije UN-a koja promovira socijalnu pravdu i međunarodno priznata ljudska i radnička prava, osnovane 1919. pa je obvezna postupati u skladu s odrednicama istih (Učur, Laleta, 2007.). RH je članica Europske unije (EU) od 1. srpnja 2013. pa je pravni poredak EU-a nadređen pravnom poretku $\mathrm{RH}$. U Povelji o temeljnim pravima EU utvrđeno je pravo radnika EU-a na poštene i pravične radne uvjete kojima se čuvaju zdravlje, sigurnost i dostojanstvo (čl. 31.). Sadržaj toga prava radnika određuju i okvirna Direktiva Vijeća 89/391/ EEZ od 12. lipnja 1989. o uvođenju mjera za poticanje poboljšanja sigurnosti i zaštite zdravlja radnika na radu, Direktiva Vijeća 91/383/EEZ od 25. lipnja 1991. o dopunama mjera za poticanje poboljšanja sigurnosti i zdravlja na radu radnika u radnom odnosu na određeno vrijeme ili privremenom radnom odnosu i dr.
U RH doneseni su propisi zbog usklađivanja pravnoga poretka s direktivama EU-a o zaštiti zdravlja, dostojanstva i sigurnosti na radu i u vezi s radom, i to primarno Zakon o radu (ZR) i Zakon o zaštiti na radu (ZZNR) te propisi zbog provedbe tih zakona (Čavrak et al., 2014:14). Dostojanstvo radnika štiti se i antidiskriminacijskim direktivama te propisima donesenim u $\mathrm{RH}$ zbog provedbe istih. U Ustavu RH jamči se pravo na zaradu za slobodan i dostojanstven život pojedinca i obitelji (čl. 55.). ZR propisuje pravo poslodavca pobliže odrediti mjesto i način obavljanja rada, poštujući pri tome prava i dostojanstvo radnika te obvezu osigurati radniku uvjete za rad na siguran način $\mathrm{i}$ na način koji ne ugrožava zdravlje radnika (čl. 7.). Osim toga, zabranjuje izravnu ili neizravnu diskriminaciju na području rada i uvjeta rada [6:458] te propisuje obvezu poslodavcu zaštititi dostojanstvo radnika za vrijeme obavljanja posla od postupanja nadređenih, suradnika i osoba s kojima radnik redovito dolazi u doticaj u obavljanju svojih poslova, ako je takvo postupanje neželjeno i u suprotnosti s ovim Zakonom i posebnim zakonima. Pored toga, radniku je zakonom (čl. 134. ZR-a) osigurana samozaštita od uznemiravanja i spolnog uznemiravanja na način da, ako mu poslodavac ne osigura zaštitu, ima pravo prekinuti rad uz naknadu plaće kao da je radio (Pivčević, 2017.:451). Dakle, radnik u RH ne može se odreći dostojanstva na radu, ono se ne može ograničiti jer je urođeno ljudskoj osobi i sastavni je dio svih prava na radu i u vezi s radom (Šokčević, 2016.:6).

Dostojanstvo radnika jedno je od temeljnih prava iz radnoga odnosa. Postupak i mjere zaštite dostojanstva radnika od uznemiravanja i spolnog uznemiravanja uređuju se posebnim zakonom, kolektivnim ugovorom, sporazumom sklopljenim između radničkoga vijeća i poslodavca ili pravilnikom o radu (čl. 134. ZR-a). U slučaju bilo kakvog uznemiravanja na radnome mjestu radnik isto treba prijaviti svojem poslodavcu, a ako poslodavac zapošljava najmanje dvadeset radnika, obvezan je imenovati i osobu koja je osim njega ovlaštena primati i rješavati pritužbe u vezi sa zaštitom dostojanstva radnika. Poslodavac je obvezan procijeniti sve rizike na radu, zaštititi radnike od istih te mora zaštititi radnika od svih neželjenih loših ponašanja koja mogu ugroziti zdravlje i sigurnost radnika. 
Novitet u hrvatskom zakonodavstvu je Zakon o zaštiti prijavitelja nepravilnosti (ZZPN) koji je stupio na snagu 1.7.2019. kojemu je cilj učinkovita zaštita prijavitelja nepravilnosti kojima se krše zakoni i drugi propisi, te zaštita prijavitelja nesavjesnog upravljanja javnim dobrima, javnim sredstvima i sredstvima EU-a koje predstavlja ugrožavanje javnog interesa, a koja su povezana s obavljanjem poslova kod poslodavca. Ovim zakonom utvrđeni su novi standardi na razini $\mathrm{RH}$ za zaštitu "zviždača“, prijavitelji se štite od sankcije poslodavca koje bi bile povezane s prijavom te se njime jača svijest i potiču građani na prijavljivanje nepravilnosti o kojima imaju saznanja, a povezani su s obavljanjem poslova kod poslodavca.

\section{Važnost prevencije rizika za život $\mathbf{i}$ zdravlje radnika}

ZZNR u čl. 51. propisuje da je poslodavac obvezan provoditi prevenciju stresa na radu ili u vezi s radom koji je uzrokovan osobito čimbenicima kao što su sadržaj rada, organizacija rada, radno okruženje, loša komunikacija i međuljudski odnosi, kako bi sveo na najmanju mjeru potrebu radnika da svladava poteškoće zbog dugotrajnije izloženosti intenzivnom pritisku te otklonio mogućnost da se umanji radna učinkovitost radnika i pogorša njegovo zdravstveno stanje.

ZZNR ne uređuje pojam mobinga već uređuje pojam stresa na radu. Razlika je u tome što stres na radu može, ali ne mora biti mobing. Pojam stresa na radu širi je od pojma mobinga jer mobing podrazumijeva ponašanje jedne ili više osoba prema drugoj kojim se ciljano psihički zlostavlja i ponižava drugu osobu, dok stres na radu podrazumijeva zdravstvene i psihičke promjene do kojih je došlo zbog dugotrajnog utjecaja stresora na radu, a koje nužno ne moraju biti posljedica ljudskog faktora, odnosno ponašanja neke osobe koje za cilj ima ugrožavanje ugleda, časti, ljudskoga dostojanstva i integriteta druge osobe (Vinković et al., 2016.). Ako postoje naznake stresa na radu ili u vezi s radom, poslodavac je obvezan posebnu pozornost usmjeriti na organizaciju rada i radnih postupaka, radne uvjete i okolinu, komunikaciju i subjektivne čimbenike (Smitha et al., 2001.). Radnici trebaju biti upoznati sa svojim pravima, zajamčenim zakonskim propisima, primjerice da dožive mobing, a recen- tna istraživanja su pokazala da primjerice, policijski službenici nedovoljno dobro poznaju svoja prava za slučaj da budu izvrgnuti mobingu na radnome mjestu (Juras, Mravak, 2015.:50). Pored toga, bitno je propisati jasne sankcije za kršenje odredbi o odgovornosti poslodavca (Pivčević, Erceg Ćurić, 2019.:205). Preveliki zahtjevi radnoga okruženja nedvojbeno imaju negativne posljedice na zdravlje i sigurnost radnika, što je prepoznato na razini EU-a pa sve države članice obvezuju odredbe direktiva koje sadrže zahtjeve i standarde zaštite. Sofisticirani mehanizmi i pravila zaštite (npr. kodeksi ponašanja, posebni alati i standardi), koji će odgovarati karakteristikama pojedine djelatnosti ili poslodavca, ukazuju se učinkovitijima od samog zakonodavstva. Osobitu ulogu u zaštiti radnika ima kvalitetan socijalni dijalog i kolektivno pregovaranje te menadžment osposobljen za upravljanje psihosocijalnim rizicima i stresom na radu, naročito kod atipičnih oblika rada (Laleta, Senčur Peček, 2017.:327). Naime, atipični oblik rada često vodi $k$ lošijim uvjetima rada od onih koje imaju radnici u standardnom radnom odnosu npr. predugo ili nepredvidivo radno vrijeme. No, u nekim slučajevima atipičan rad jest dobrovoljan izbor radnika pa se ne može govoriti o smanjenoj zaštiti zdravlja radnika. Tako Sud Europske unije u presudi br. C-147/17 od 20.11.2018. izražava stajalište, da članak 1., stavak 3. Direktive 2003/88/ EZ Europskog parlamenta i Vijeća od 4.11.2003. o određenim vidovima organizacije radnog vremena, u vezi sa člankom 2., stavkom 2. Direktive Vijeća 89/391/EEZ od 12.6.1989. o uvođenju mjera za poticanje poboljšanja sigurnosti i zdravlja radnika na radu, treba tumačiti na način, da u područje primjene Direktive 2003/88 ne ulazi djelatnost profesionalnog udomiteljstva koja se unutar radnog odnosa s javnim tijelom sastoji od prihvata i uključenja djeteta u vlastiti dom te neprekidnog osiguranja njegova skladnog razvoja i obrazovanja.

Pravo radnika na prekid rada, koje predviđa ZZNR, zakonom je osigurana samozaštita radnika od uznemiravanja i spolnog uznemiravanja u slučajevima kada mu poslodavac ne osigura zaštitu, uz obvezu poslodavca na naknadu plaće radniku kao da je radio. Radi se o bitnom pravu radnika u svjetlu propisa za zaštitu dostojanstva, koje predstavlja preventivnu mjeru u slučaju rizika za zdravlje. ZZNR-om propisano je da radnik ima 
pravo odbiti raditi i napustiti mjesto rada ako mu izravno prijeti rizik za život i zdravlje, sve dok poslodavac ne poduzme korektivne mjere (čl. 68.). Nadalje, zbog takvoga postupanja radnik ne smije trpjeti štetne posljedice (čl. 69., st. 4. ZZNRa). Poslodavac ne smije zahtijevati od radnika da ostane na mjestu rada dok na tome mjestu postoji izravan i ozbiljan rizik za život i zdravlje radnika (čl. 69., st. 5. ZZNR-a).

Poslodavac ne smije dopustiti ni obavljanje poslova s posebnim uvjetima rada radniku koji ne ispunjava uvjete propisane posebnim propisom za takve poslove (čl. 36. ZZNR-a). Poslovi s posebnim uvjetima rada su poslovi koje zbog sprečavanja štetnog utjecaja rada na život i zdravlje radnika (ozljeda na radu, profesionalnih bolesti, bolesti u vezi s radom i sl.) mogu obavljati samo osobe koje osim općih uvjeta za zasnivanje radnog odnosa ispunjavaju i propisane posebne uvjete, ovisno o vrsti posla. Poseban propis koji definira poslove s posebnim uvjetima rada kao i posebne uvjete u tom smislu je Pravilnik o poslovima s posebnim uvjetima rada. Prilikom organiziranja radnog vremena na poslovima s posebnim uvjetima rada postoji obveza poslodavca da vodi računa o zdravlju i sigurnosti na radu. U sudskoj praksi postavlja se pitanje, ulazi li dežurstvo u radno vrijeme, a o čemu onda ovisi plaćanje radnog vremena. Sud Europske unije u presudi br. C-518/15 od 21.2.2018. izrazio je stav da određene oblike organizacije radnog vremena treba tumačiti na način da države članice ne mogu u pogledu određenih kategorija vatrogasaca zaposlenih u javnoj vatrogasnoj službi - odstupiti od obveza koje proizlaze iz članka 17., stavak 3., točka (c), podtočka iii. Direktive 2003/88/EZ Europskog parlamenta i Vijeća od 4.11.2003., uključujući njezin članak 2. koji definira, među ostalim, pojmove "radno vrijeme" i „vrijeme odmora". Nadalje, Europski sud ističe da članak 15. Direktive treba tumačiti na način da se ne dopušta zadržavanje ili donošenje manje ograničavajuće definicije pojma "radno vrijeme" od one navedene u čl. 2. te Direktive; da članak 2. Direktive 2003/88 treba tumačiti na način da države članice ne obvezuje na to da plaću za pasivna dežurstva utvrde s obzirom na kvalifikaciju tih dežurstava kao "radnog vremena", odnosno "vremena odmora" i da čl. 2. Direktive 2003/88 treba tumačiti na način da dežurstvo koje radnik obavlja u svojem domu, uz obvezu javljanja na pozive poslodavca u roku od 8 minuta, znatno ograničava mogućnost obavljanja drugih aktivnosti pa da se valja smatrati "radnim vremenom".

Posebni uvjeti za obavljanje poslova s posebnim uvjetima rada, ovisno o vrsti posla, mogu sadržavati zahtjeve povezane s: dobi života (svi poslovi zahtijevaju određenu dob, najčešće radnik mora biti stariji od 18 godina), spolom (određene poslove ne mogu obavljati žene za vrijeme trudnoće i dojenja npr. poslove koji zahtijevaju teško fizičko naprezanje ili rad poslova u nepovoljnoj mikroklimi), zdravstvenim stanjem i psihičkom sposobnosti. Sud Europske unije u presudi br. C-41/17 od 12.11.2018. napominje da članak 7. Direktive 92/85/EEZ od 19.10.1992. o uvođenju mjera za poticanje poboljšanja sigurnosti i zdravlja na radu trudnih radnica te radnica koje su nedavno rodile ili doje, treba tumačiti na način da se primjenjuje na situaciju poput one u glavnom postupku, u kojoj predmetna radnica obavlja rad u smjenama u okviru kojeg samo dio svojih dužnosti izvršava u noćnoj smjeni. Nadalje napominje da članak 19., st. 1. Direktive 2006/54/ EZ Europskog parlamenta i Vijeća od 5.7.2006. o provedbi načela jednakih mogućnosti i jednakog postupanja prema muškarcima i ženama u pitanjima zapošljavanja i rada treba tumačiti na način da se primjenjuje na konkretnu situaciju u kojoj je radnici odbijeno izdavanje liječničkog certifikata kojim se potvrđuje postojanje opasnosti za dojenje povezane s njezinim radnim mjestom i, posljedično, novčana naknada zbog opasnosti tijekom dojenja pred nacionalnim sudom ili drugim nadležnim tijelom predmetne države članice, ako ta radnica iznese činjenice koje upućuju na to da ta procjena nije uključivala pojedinačno ispitivanje koje uzima u obzir njezinu individualnu situaciju i na temelju kojih se stoga može pretpostaviti, postojanje izravne diskriminacije na temelju spola u smislu Direktive 2006/54, što je na sudu koji je uputio zahtjev da provjeri.

\section{Posljedice ozljeda na radu i sudski postupci}

Propisima o zaštiti na radu uređuju se prava, obveze i odgovornost poslodavca i radnika, u pogledu zdravstvenih, socijalnih i drugih mjera, zbog zaštite života, zdravlja, radne i životne okoline radnika na radu. Brojnost tih pravnih izvora 
ukazuje na značaj zaštite na radu u svim djelatnostima (European Agency for Safety and Health at Work, 2019.). Zaštitu na radu pružaju poslodavci (Rundmo, Hale, 2003.), stručnjaci za zaštitu na radu, a nadziru inspektori rada i zaštite na radu, dok sporove rješavaju stvarno i mjesno nadležni sudovi.

Pri obavljanju poslova primjenjuju se pravila zaštite na radu kojima se uklanja ili smanjuje opasnost na sredstvima rada (Dejoy, 2005.). Poslodavac odgovara za štetu koju pretrpi radnik na radu pri obavljanju radnog zadataka prema kriteriju objektivne odgovornosti (čl. 15. ZZR), koje odgovornosti se može osloboditi samo u slučaju ako dokaže da je šteta nastala zbog više sile, protupravnog djelovanja treće osobe ili krivnjom samog radnika. Ako poslodavac propusti primijeniti pravila zaštite na radu, dužan je naknaditi štetu radniku koja mu je nastala ozljedom na radu. To je potvrđeno u praksi sudova pa tako, Županijski sud u Rijeci u odluci br. Gž R-567/17 od 6.3.19. navodi, da u situaciji kada se radnik ozlijedi na stubama koje se nalaze u radnom okolišu poslodavca, a koje nisu održavane već su bile oštećene i nisu imale rukohvat, da je tada poslodavac odgovoran tužiteljici za nastalu štetu i kao poslodavac i kao suvlasnik predmetne nekretnine. $U$ tom slučaju poslodavac odgovara radniku prema načelu objektivne odgovornosti odnosno, kao poslodavac odgovara u skladu s odredbom članka 103., stavak 1. Zakona o radu (N.N., br. 149/09.) i članka 15. Zakona o zaštiti na radu (N.N., br. 59/96., 94/96. - ispravak 114/03., 100/04., 86/08., 116/08. i 75/09) u svezi sa člankom 1064. Zakona o obveznim odnosima (ZOO), u skladu s kojim zakonom (ZOO), odgovara i kao suvlasnik predmetne nekretnine i stuba.

Posljedice ozljede na radu i profesionalne bolesti su pogoršanje dotadašnjeg tjelesnog zdravlja radnika, osobito kod težih tjelesnih ozljeda i zaostalog smanjenja životnih aktivnosti pa su zbog toga i radne sposobnosti umanjene. $U$ tome pravcu posljedice trpi poslodavac jer radnika koji je pretrpio ozljedu na radu moguće treba premjestiti na drugo radno mjesto, dok takav radnik obavlja aktivnosti uz povećane napore i posebne uvjete te ima manje šanse za napredovanje, specijalizaciju i sl. Prema odredbi čl. 1095., st. 2. ZOO-a, ako ozlijeđeni zbog potpune ili djelomične nesposobnosti za rad gubi zaradu, ili su mu potrebe traj- no povećane, ili su mogućnosti njegova daljnjeg razvijanja i napredovanja uništene ili umanjene, odgovorna osoba dužna je plaćati ozlijeđenomu određenu novčanu rentu, kao naknadu za štetu (primjerice, odluka Županijskog suda u Bjelovaru, br. Gž R-3/16 od 26.4.2018.). Odredbom čl. 1096. ZOO-a određeno je da sud može na zahtjev oštećenika za ubuduće povećati rentu, a da je može na zahtjev štetnika sniziti ili ukinuti ako se znatnije promijene okolnosti koje je sud imao na umu pri donošenju prijašnje odluke.

ZOO propisuje da svaka fizička i pravna osoba ima pravo na zaštitu svojih prava osobnosti pod pretpostavkama utvrđenim zakonom, a pod pravima osobnosti da se u smislu ovoga Zakona razumijevaju prava na život, tjelesno i duševno zdravlje, ugled, čast, dostojanstvo, ime, privatnost osobnog i obiteljskog života, slobodu i dr. (čl. 19.). Svatko ima pravo zahtijevati od suda ili drugoga nadležnog tijela da naredi prestanak radnje kojom se povređuje pravo njegove osobnosti i uklanjanje njome izazvanih posljedica (čl. 1048. ZOO-a). ZOO (čl. 1100.) propisuje da će sud, u slučaju povrede prava osobnosti, ako nađe da to težina povrede i okolnosti slučaja opravdavaju, dosuditi pravičnu novčanu naknadu, nezavisno od naknade imovinske štete, a i kad nje nema (Blanpain, 2014.). Pri odlučivanju o visini pravične novčane naknade sud će voditi računa o jačini i trajanju povredom izazvanih fizičkih boli, duševnih boli i straha, cilju kojemu služi ta naknada, ali i o tome da se njome ne pogoduje težnjama koje nisu spojive s njezinom naravi i društvenom svrhom.

ZR (čl. 111.) propisuje da je, ako radnik pretrpi štetu na radu ili u svezi s radom, poslodavac dužan radniku naknaditi štetu prema općim propisima obveznoga prava. Ozljeda na radu i profesionalna bolest koju je radnik pretrpio obavljajući poslove za poslodavca smatra se da potječe od rada i poslodavac za nju odgovara po načelu objektivne odgovornosti (čl. 25. ZZNR). Poslodavac može biti oslobođen odgovornosti ili se njegova odgovornost može umanjiti ako je šteta nastala zbog više sile, odnosno namjerom ili krajnjom nepažnjom radnika ili treće osobe, na koje poslodavac nije mogao utjecati niti je njihove posljedice mogao izbjeći, unatoč provedenoj zaštiti na radu. Prema općim propisima obveznoga prava (čl. 1067. ZOO-a) vlasnik se oslobađa odgo- 
vornosti ako dokaže da je šteta nastala isključivo radnjom oštećenika ili treće osobe, koju on nije mogao predvidjeti i čije posljedice nije mogao ni izbjeći, ni otkloniti, a oslobađa se djelomično ako je oštećenik djelomično pridonio nastanku štete. Primjerice, u pravomoćnoj presudi Općinskog suda u Splitu br. Pr-437/11 od 7. rujna 2015., utvrđeno je da je tuženik (poslodavac), neovisno o tome što je na stroju bilo postavljeno upozorenje o neispravnoj zaštiti, morao obustaviti svaki rad na stroju te organizirati obavljanje posla na način da ne utječe štetno na sigurnost i zdravlje radnika (tužitelja). Stoga je sud zaključio kako nisu osnovane tvrdnje tuženika da bi tužitelj bio isključivo odgovoran za nastanak predmetnog štetnog događaja jer je utvrđeno kako je tužitelja prikliještio dio stroja koji je pao zbog neispravne zaštite, a u postupku nije dokazano da je tuženik sredstvo rada koje nije bilo $u$ ispravnom stanju, osigurao na način da ne ugrožava sigurnost i zdravlje radnika. Stoga je tuženik, koji se bavi opasnom djelatnosti utvrđen odgovornim za štetu tužitelju do koje je došlo zbog objektivne odgovornosti tuženika. Međutim, u konkretnom slučaju, sud je zaključio da na strani tužitelja postoji suodgovornost za nastanak štetnog događaja, jer je išao raditi poslove na stroju na koji nije raspoređen i za koje nije osposobljen za rad na siguran način, unatoč istaknutom upozorenju o neispravnosti fotozavjese. Stoga da kritične prigode nije postupio s dužnom pažnjom, čime je pristao i na posljedice takvog rada te je sud utvrdio da je isti suodgovoran za nastanak radne nezgode u omjeru od $40 \%$ pa je u tome omjeru umanjena visina pravične novčane naknade za koju je utvrđeno da bi mu pripadala.

\section{CILJ ISTRAŽIVANJA}

Istraživanje ima za cilj kroz sudske postupke koji se vode pred Općinskim sudom u Splitu utvrditi koliko se postupaka vodi zbog povrede prava radnika na zaštitu zdravlja i sigurne uvjete rada, sadržaj tužbenih zahtjeva u tim postupcima, koji je ishod spora i koliko na ishod utječe poštovanje propisa i mjera kojima se štite zdravlje, sigurnost i dostojanstvo radnika. Nakon analize pravnih propisa o pravu radnika na zaštitu zdravlja i sigurne uvjete rada, i sudskih postupaka koji se vode zbog povrede navedenih prava, cilj je ukazati na značaj provođenja propisanih mjera zaštite u radnome okruženju. Cilj je u tome pravcu znanstvenom obradom ove teme pokušati utjecati na poboljšanje, unapređivanje i ujednačavanje pravne regulacije ove materije.

\section{Hipoteze}

Na temelju uočenoga problema, koji je predmet analize u ovome radu, definirana je glavna hipoteza ovoga istraživanja: od iznimne je važnosti pravovremeno i detaljno upoznavanje sudionika radnoga odnosa s propisanim mjerama zaštite na radu i sudskim postupcima i posljedicama koje proizlaze zbog nepoštovanja propisa za radnika i poslodavca jer sudska praksa pokazuje da radni uvjeti nisu usklađeni s propisima o uvjetima rada kojima se čuvaju sigurnost, zdravlje i dostojanstvo radnika. Iz glavne hipoteze izvedene su daljnje hipoteze:

$\mathrm{H1}$ : Brojni su postupci koji se vode pred sudom zbog povrede prava radnika na zaštitu zdravlja i sigurne uvjete rada.

H2: Različit je sadržaj pravne zaštite.

H3: Ishod sporova pred sudom je neizvjestan.

H4: Glavni uzrok povrede prava radnika je taj što se propisi i mjere kojima se štite zdravlje, sigurnost i dostojanstvo na radu i u vezi s radom ne provode u cijelosti.

\section{Zadaci}

U cilju istraživanja provedeno je sljedeće:

- Izvršen uvid u Informacijski sustav Ministarstva pravosuđa $\mathrm{RH}$ (e-spis).

- Obavljeno istraživanje na utvrđenom uzorku (postupci koji se vode pred Općinskim sudom u Splitu zbog povrede prava radnika na zaštitu zdravlja i sigurne uvjete rada, u razdoblju od 2015. do 1.9.2019.)

- Istražen i statistički analiziran ishod navedenih postupaka.

- Prikazani i interpretirani dobiveni rezultati, uz raspravu i zaključak. 


\section{METODE}

$U$ radu su primijenjene različite metode istraživanja: normativna, dogmatska, teleološka, gramatička, logička, komparativna, metoda deskriptivne analize, korištenjem literature i propisa. Autorice daju komparativu analizu te iznose prijedloge de lege ferenda. Ostvarivanje ciljeva istraživanja i provjera postavljenih hipoteza moguća je samo uz povezivanje teorije i prakse pa se provelo teoretsko-empirijsko istraživanje, a za analizu podataka korištena je statistička metoda uz izražavanje rezultata u postocima. Istraživanje je obuhvatilo postupke koji se vode pred Općinskim sudom u Splitu zbog povrede prava radnika na zaštitu zdravlja i sigurne uvjete rada tijekom 2015., 2016., 2017., 2018. i 2019. (do 1.9.2019.).

\section{REZULTATI}

Podaci dobiveni iz Informacijskog sustava Ministarstva pravosuđa Republike Hrvatske (e-spis) obuhvaćaju tužbe pred Općinskim sudom u Splitu podnesene u razdoblju od 2015. do 1.9.2019. godine zbog povrede prava radnika na zaštitu zdravlja i sigurne uvjete rada.

Analizom navedenih podataka utvrđeno je da je u promatranom razdoblju pred Općinskim sudom u Splitu pokrenut 381 postupak zbog povrede prava radnika na zaštitu zdravlja i sigurne uvjete rada, od čega je dovršeno 146, a 235 je u tijeku.

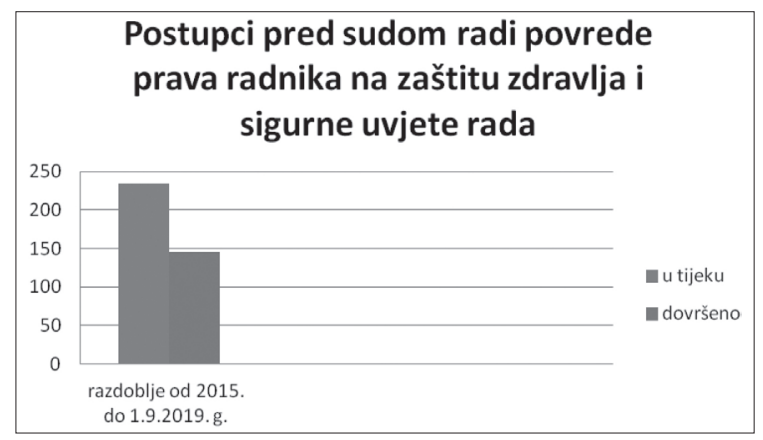

Izvor: Autori na temelju podataka Informacij. sustava Ministarstva pravosuđa, rujan 2019.

Slika 1. Broj pokrenutih i dovršenih postupaka pred sudom zbog povrede prava radnika na zaštitu zdravlja i sigurne uvjete rada od 2015. do 1.9.2019. g.

Figure 1. Number of concluded court cases involving the rights of workers to occupational safety and safe working conditions, 2015 - 1st September 2019
U postupcima koji su se u promatranom razdoblju vodili pred sudom zbog povrede prava radnika na zaštitu zdravlja i sigurne uvjete rada, tužbeni zahtjevi u 93 \% slučajeva glase na naknadu štete (kondemnatorni zahtjev) koju radnik trpi zbog ozljede na radu i u svezi s radom, u $6 \%$ slučajeva glasi na utvrđenje, zabranu i otklanjanje diskriminacije (deklaratorni + kondemnatorni zahtjev), a u svega $1 \%$ slučajeva glasi na poduzimanje mjera zbog otklanjanja uzroka i sprečavanja ponavljanja uznemiravanja (kondemnatorni zahtjev).

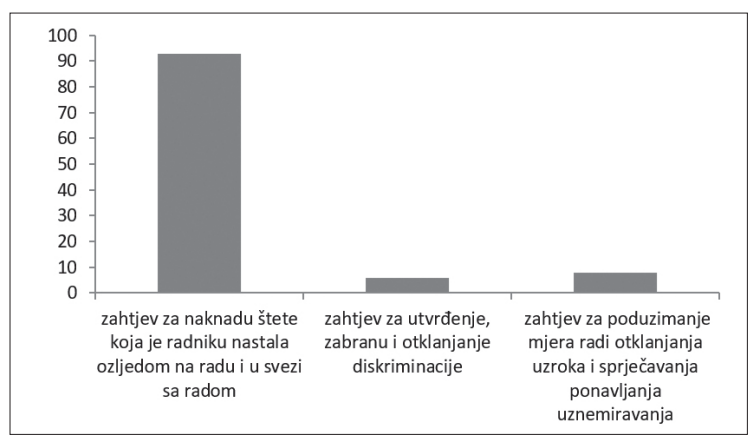

Izvor: Autori na temelju podataka Informacij. sustava Ministarstva pravosuđa, rujan 2019.

Slika 2. Sadržaj tužbenih zahtjeva u postupcima koji se vode pred sudom zbog povrede prava radnika na zaštitu zdravlja i sigurne uvjete rada od 2015. do 1.9.2019. g.

Figure 2. Actual content of the court cases initiated due to violations of workers' rights to occupational safety and safe working conditions, 2015 - 1st September 2019

Prikupljeni podaci o ishodu postupaka koji su se vodili pred sudom u predmetnom razdoblju zbog povrede prava radnika na zaštitu zdravlja i sigurne uvjete rada ukazuju na to da je radnicima tužbeni zahtjev prihvaćen u $63 \%$ slučajeva, a odbijen u 37 \% slučajeva.

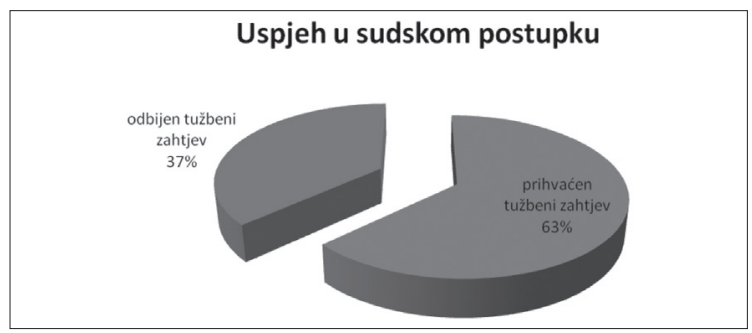

Izvor: Autori na temelju podataka Informacij. sustava Ministarstva pravosuđa, rujan 2019.

Slika 3. Uspjeh u sudskom postupku po tužbama zbog naknade štete radi ozljede na radu i u svezi s radom

Figure 3. Court cases successfully ended with compensation for injuries at work and related to working conditions 
Na osnovi prikupljenih podataka za promatrano razdoblje uočava se da je glavni uzrok povrede prava radnika taj što poslodavac u $50 \%$ slučajeva ne provodi u cijelosti propise i mjere kojima se štite zdravlje, sigurnost i dostojanstvo na radu i u vezi s radom. Odmah potom, kao najčešći uzrok povrede prava radnika, slijedi radnja oštećenika, drugog radnika ili treće osobe u 42 \% slučajeva, a u $8 \%$ slučajeva su ostali uzroci povreda kao što su viša sila, neispravna sredstva za rad i dr.

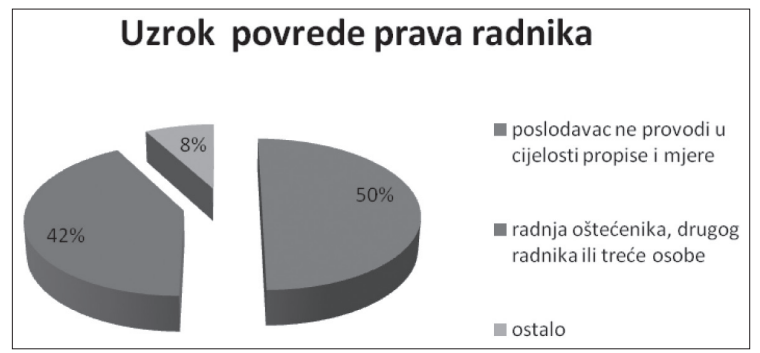

Izvor: Autori na temelju podataka Informacij. sustava Ministarstva pravosuđa, rujan 2019.

Slika 4. Uzrok povrede prava radnika na zaštitu zdravlja i sigurne uvjete rada u postupcima pred sudom od 2015. do 1.9.2019. g.

Figure 4. Causes of violation of workers' right to occupational safety and safe working conditions in court proceedings, 2015 - 1st September 2019

\section{RASPRAVA}

Na temelju promatranih podataka vidljivo je da se pred Općinskim sudom u Splitu vode brojni postupci zbog povrede prava radnika na zaštitu zdravlja i sigurne uvjete rada, čime je potvrđena 1. hipoteza. Rezultati istraživanja pokazuju da je u razdoblju od 2015. do 1.9.2019., od ukupno pokrenutih postupaka zbog povrede prava radnika na zaštitu zdravlja i sigurne uvjete rada, dovršeno njih $40 \%$.

Iz analize utvrđenih podataka proizlazi da u navedenim postupcima radnici traže različitu pravnu zaštitu. U većini slučajeva radnici traže naknadu štete zbog ozljede na radu i u svezi s radom, dok u manjem broju slučajeva traže utvrđenje, zabranu i otklanjanje diskriminacije ili provođenje mjera zbog otklanjanja uzroka i sprečavanja ponavljanja uznemiravanja. Moguće da žrtve diskriminacije i mobinga (uznemiravanja) ne žele voditi sudske postupke jer je ishod neizvjestan, postupci iziskuju materijalne troškove, a mogu narušiti međuljudske odnose na radnome mjestu. Rezultati istraživanja ukazuju i na to da je radnike potrebno upoznati s njihovim pravima za slučaj da dožive mobing, ohrabriti ih na prijavljivanje mobinga pa ako poslodavac bude nespreman ispitati slučaj i otkloniti uzrok mobinga, tada jedini izlazak predstavlja podnošenje tužbe nadležnome sudu. Dobiveni podaci potvrđuju 2. hipotezu.

Osim što je utvrđeno da je 37 \% tužbenih zahtjeva odbijeno, za preostale tužbene zahtjeve utvrđeno je da nisu svi prihvaćeni u cijelosti. Navedeno ovisno o tome postoji li podijeljena odgovornost za nastalu štetu, ovisno o rezultatima provedenoga vještačenja ili konkretnoj imovinskoj šteti koja je nastala, a što potvrđuje 3. hipotezu da je ishod sporova pred sudom neizvjestan.

Utvrđivanjem činjenica uzroka ozljede na radu uočeno je da pojedini poslodavci ne izvršavaju obvezu osiguranja radilišta, mjesta rada i radnoga okoliša za rad na siguran način, da radnici nisu dostatno educirani i upoznati s opasnostima na njihovim radnim mjestima pa da nerijetko obavljaju poslove na način koji ugrožava život i zdravlje radnika, čime je potvrđena 4. hipoteza, odnosno da je glavni uzrok povrede prava radnika taj što se propisi i mjere kojima se štite zdravlje, sigurnost i dostojanstvo na radu i u vezi s radom ne provode u cijelosti.

\section{ZAKLJUČAK}

Istraživanje je pokazalo da se propisi koji se odnose na regulaciju zaštite na radu i propisane mjere zaštite i prevencije ne provode u cijelosti. Posljedice povreda na radu su ozbiljne kako za radnika tako i poslodavca pa ih je bitno uočiti zbog pravovremenog otklanjanja uzroka, a pravilnim i dosljednim provođenjem zakonom i drugim aktima propisanih mjera zaštite na radu smanjit će se broj povreda prava radnika i sudskih postupaka s time u vezi. Iz rezultata istraživanja proizlazi da je važno poznavanje i detaljno provođenje propisanih mjera zaštite na radu, kao i da je od značaja poznavati sadržaj pravne zaštite u slučaju povrede prava.

Istraživanje ukazuje da se u radnome procesu nedovoljno poštuju propisi koji se odnose na uvjete rada što u znatnom broju slučajeva rezul- 
tira ozljedom na radu. lako je ova problematika u RH zakonski regulirana i usklađena s direktivama i drugim propisima EU-a, potrebno je i nadalje educirati radnike i poslodavce o pravima i obvezama u radnome procesu, kao i ukazati im na važnost preventivnih mjera. Potrebno je i na ovome mjestu istaknuti važnost provođenja pravilnog i pravovremenog osposobljavanja radnika o sigurnim uvjetima rada te potaknuti sudionike radnoga odnosa na prijavljivanje uočenih nepravilnosti u radnome okruženju. S obzirom na navedeno, valjalo bi jasno kreirati normativni okvir koji ne bi ostavljao dvojbe o odgovornosti za štetu poslodavca i suodgovornosti radnika u slučaju povrede prava radnika na zaštitu zdravlja i sigurne uvjete rada, sve zbog ostvarenja veće pravne sigurnosti.

Profesionalni rizici koje poslodavci moraju ocijeniti nisu utvrđeni jednom zauvijek, već se kontinuirano mijenjaju ovisno o razvoju uvjeta rada i znanstvenom istraživanju takvih rizika. Predmetno istraživanje stoga ukazuje na potrebu budućeg istraživanja slučajeva povrede propisa u procesu rada, podataka o uzrocima i posljedicama nezgoda na radu, brojnosti i ishodu sudskih sporova zbog povreda prava radnika na sigurne uvjete rada, posebno radi dobivanja cjelovite slike o uzrocima i posljedicama ozljeda te o potrebi unapređenja zakonskih odredbi koje reguliraju ovu materiju.

\section{LITERATURA}

Barić Punda, V.: Načelo nediskriminacije jedno od temeljnih načela zaštite ljudskih prava i sloboda, Zbornik radova Pravnog fakulteta u Splitu, god. 42, 2005., str. 27-42.

Blanpain, R.: European Labour Law, Kluwer Law International, The Netherlands, 2014.

Crnić, I.: Povreda prava osobnosti i naknada neimovinske štete u radnom odnosu, Zbornik Aktualna pitanja ostvarivanja $i$ zaštite prava iz radnih odnosa, Inž. biro, Zagreb, 2007.

Čavrak, D., Frntić, D. F., Gović Penić, I., Gruban, M., Milković, D., Novaković, N., Rožman, K.: Detaljni komentar novoga Zakona o radu, Radno pravo, Rosip d.o.o., Zagreb, 2014.

Dejoy, D. M.: Behaviour change versus culture change: Divergent approaches to managing workplace safety, Safety Science, 43, 2005., 2, str. 105-129.

Direktiva Vijeća 89/391/EEZ od 12. lipnja 1989. o uvođenju mjera za poticanje poboljšanja sigurnosti i zaštite zdravlja radnika na radu, SL L 183, 29. lipnja 1989.

Direktiva Vijeća 91/383/EEZ od 25. lipnja 1991. o dopunama mjera za poticanje poboljšanja sigurnosti i zdravlja na radu radnika u radnom odnosu na određeno vrijeme ili privremenom radnom odnosu, SL L 206, 29. srpnja 1991.

Direktiva Vijeća 92/85/EEZ od 19. listopada 1992. o uvođenju mjera za poticanje poboljšanja sigurnosti i zdravlja na radu trudnih radnica te radnica koje su nedavno rodile ili doje, SL L 348, 28. studenoga 1992.

Erceg Ćurić, I.: Načelo zabrane diskriminacije na radu, s posebnim osvrtom na praksu Općinskog suda u Splitu, Godišnjak, 24, Aktualnosti hrvatskog zakonodavstva i pravne prakse, Organizator, Zagreb, 2017., str. 457-464.

EUR-Lex pristup zakonodavstvu Europske unije, dostupno na: https://eur-lex.europa.eu, pristupljeno: 23.9.2019.

European Agency for Safety and Health at Work, dostupno na: https://osha.europa.eu/hr, pristupljeno: 1.3.2019.

Geldart, S., Smith, C.A., Shannon, H.S., Lohfeld, I.: Organizational practices and workplace health and safety: A cross - sectional study in manufacturing companies, Safety Science, 48, 2010., 5, str. 562-569.

Informacijski sustav Ministarstva pravosuđa Republike Hrvatske - e-spis, rujan 2019.

Juras, D., Mravak, M.: Policijski službenici i mobing, Management and Safety, 10, 2015., str. 46-56.

Kazneni zakon, N.N., br. 125/11., 144/12., 56/15., 61/15.

Konvencije MOR-a koje je $R H$ ratificirala: Konvencija br. 17 o naknadi koja se isplaćuje radnicima za slučaj nesreće na radu, NN - MU 1/02.; Konvencija br. 155 o sigurnosti i zaštiti zdravlja na radu i u radnom okruženju, NN - MU 11/03. 
Laleta, S., Senčur Peček, D.: Atipični rad - izazovi zaštite od psihosocijalnih rizika i stresa na radu i u vezi s radom, Sigurnost, 59, 2017., 4, str. 315-330.

Međunarodni pakt o ekonomskim, socijalnim i kulturnim pravima, SI. list SFRJ, br. 7/91.

Opća deklaracija o ljudskim pravima, Narodne novine (NN) - Međunarodni ugovori (MU), 12/09.

Pivčević, D.: Prekid rada radi zaštite dostojanstva radnika i povrat isplaćene naknade plaće u bruto ili neto iznosu, Godišnjak, 24, Aktualnosti hrvatskog zakonodavstva i pravne prakse, Organizator, Zagreb, 2017., str. 449-455.

Pivčević, D., Erceg Ćurić, I.: Naknada štete kod povrede prava radnika na zaštitu zdravlja i sigurne uvjete rada, Management and Safety, 14, 2019., str. 198-208.

Povelja o temeljnim pravima EU, SL C 83, 30. ožujka 2010.

Pravilnik o poslovima s posebnim uvjetima rada, N.N., br. 5/84.

Pravilnik o zaštiti na radu za mjesta rada, $\mathrm{N}$. N., br. 29/13.

Pravilnik o izradi procjene opasnosti, N.N., br. 48/97., 114/02., 126/03., 144/09.

Rosa Antonia, C.: Complexity and safety, Journal of Safety Research, 42, 2011., 4, str. 293-300.

Rundmo, T, Hale, A. R.: Managers' attitudes towards safety and accident prevention, Safety Science, 41, 2003., 7, str. 557-574.

Smitha, M. W., Kirk, K. A., Oestenstad, K.R., Brown, K.C., Lee, S.D.: Effect of state workplace safety laws on occupational injury rates, Journal of Occupational and Environmental Medicine, 43, 2003., 1001-10.

Šokčević, S.: Zaštita dostojanstva i zdravlja radnika-zaštita od maltretiranja na radu i u vezi s radom, Sigurnost, 58, 2016., 1, 1-18.

Vinković, M., Vasiljević S., Gović Penić I.: Priručnik o diskriminaciji i mobbingu na radnom mjestu, Udruga za pomoć i edukaciju žrtava mobinga, Zagreb, 2016., str. 45-46.

Učur, M. Đ.: Zaštita osobe u radnom odnosu od načela do realizacije, Zbornik Pravnog fakulteta Sveučilišta u Rijeci, vol. 29, 2008., 1., str. 557-578.

Učur, M. Đ., Laleta, S.: Konvencije Međunarodne organizacije rada s komentarom, Tim press, Zagreb, 2007.

Ustav RH, N.N., br. 56/90., 135/97., 113/00., 28/01., 76/10., 5/14.

Zakon o radu, N.N., br. 93/14., 127/17.

Zakon o zaštiti na radu, N.N., br. 71/14., 118/14., 154/14., 94/18., 96/18.

Zakon o suzbijanju diskriminacije, N.N., br. 85/08., 112/12.

Zakon o ravnopravnosti spolova, N.N., br. 82/08.

Zakon o životnom partnerstvu osoba istog spola, N.N., br. 92/14.

Zakon o obveznim odnosima, N.N., br. 35/05., 41/08., 125/11., 78/15.

Zakon o zaštiti prijavitelja nepravilnosti, N.N., br. $17 / 19$. 


\section{COURT DISPUTES ARISING DUE TO THE VIOLATION OF WORKERS' RIGHTS TO OCCUPATIONAL HEALTH AND SAFETY AND SAFE WORKING CONDITIONS}

SUMMARY: The fundamental social right of a worker is the right to the working conditions that will not jeopardise his/her safety, health and dignity. The paper analyses the principle of worker protection and protection of labour and occupational rights, in addition to the presentation of legal theory and court practice. The paper also describes the court proceedings arising from the violation of workers' rights to occupational health and safety and safe working conditions according to the laws of the Republic of Croatia and the relevant EU regulations. In particular, the paper analyses the statistical data on specific labour disputes and the court practice of the Municipal Court in Split. The protection and exercise of human rights and freedoms is a complex and delicate issue, and the international law, universal and regional system of protection of human rights and freedoms represents a legal foundation for an efficient protection thereof. In this paper, we emphasised the need to analyse the EU sources of law and the case law of the EU Court of Justice in the process of delivering a judgement in order to achieve a higher level of legal security and uniformity of decisions. The authors concluded that a regular and timely implementation of prescribed measures concerning occupational health and safety of the participants in the work process decreases the violation of workers' rights and, consequently, reduces the number of court disputes arising from the violation of workers' rights to occupational health and safety and safe working conditions.

Key words: court disputes, employment law, occupational health and safety, safe working conditions

Original scientific paper Received: 2019-10-11

Accepted: 2020-02-25 